$$
\begin{gathered}
\text { NAGI-EB2 } \\
\text { NAT.4S-CR } \\
118615 \\
\text { P } 32
\end{gathered}
$$

\title{
Seasonal Cycling of Sulfur and Iron in Porewaters \\ of a Delaware Salt Marsh
}

By

\author{
Dr. George W. Luther, III \\ and \\ Dr. Thomas M. Church \\ College of Marine Studies \\ University of Delaware \\ 700 Pilottown Road \\ Lewes, DE 19958
}

February, 1987

(NASA-CR-182385) SEASONAL CYCLING OF SULEUR

AND IRON IA PORENATEBS OF A DELAWARE SALT

MARSH (Delaware Univ.) $32 \mathrm{p}$ CSCL 13B 


\begin{abstract}
An extensive pore water data set has been gathered in the Great Marsh, Delaware over various seasons, salinities, and tides. The data all point to a complimentary redox cycle for sulfur and iron which operates seasonally and tidally. Surface oxidizing conditions prevail in summer; more reducing conditions at depth during the winter. During the spring tides which flood the marsh, pyrite oxidation occurs releasing excess dissolved iron (II) and sulfate to the porewaters, and precipitating authigenic solid iron phases. The redox conditions in the porewaters of the upper zone during the summer is poised between midly oxidizing and midly reducing conditions as shown by $\mathrm{pE}$ calculations. This redox environment and intermediate iron-sulfur redox species may be important for the stimulation of plant growth (photosynthesis) and sustenance of a viable microbial community (heterotrophy and chemoautrophy).
\end{abstract}


Recently, we reported on the seasonal cycling between inorganic and organic forms of sulfur in the Great Marsh, Delaware - a high salt marsh (Luther et al, 1986b) based on a limited set of samples in March, June and November of 1984. It was suggested that the cycling of sulfur is controlled at least indirectly by the action of plant growth in the salt marsh during the spring and summer. During these seasons, the marsh soil in the upper 10-15 $\mathrm{cm}$ becomes oxidizing converting sulfide and sulfide minerals predominantly pyrite $\left(\mathrm{FeS}_{2}\right)$, to thiols and sulfate. The rate of sulfide oxidation is faster than the rate of sulfate reduction at this depth (Lord and Church,1983). Below 10-15 cm, the marsh soil is strongly reducing as a result of sulfate reduction with little or no sulfide oxidation being evident.

We proposed that the oxidation of pyrite to form thiols and iron (II) complexes likely occurs via a disproportionation reaction or through thiosulfate, one of pyrite's decomposition products. Pyrite formally contains $S(0)$ and $S(-2)$ sulfurs. The $S(0)$ sulfur may be used directly by organisms in chemosynthesis to produce sulfate whereas the $S(-2)$ would be incorporated into a thiol which can bind the released $\mathrm{Fe}(\mathrm{II})$.

Redox conditions in a high salt marsh have some similarities to those found in other reducing marine environments such as the Framvaren fjord, Norway. Oxic conditions are present in the upper 18 meters of the water column and anoxic conditions due to sulfate reduction are present below this point. The oxic-anoxic interface 
provides for sulfide oxidation which can form polysulfide ions in solution and which when coupled with $\mathrm{Fe}^{2+}$ can lead to $\mathrm{FeS}_{2}$ formation principally as pyrite framboids (Boulegue et a1, 1982).

Past work in Great Marsh (Boulegue et al,1982; Lord,1980;

Lord and Church,1983) shows that $\mathrm{FeS}_{2}$ formation is rapid and important even in the oxidized zone. Similar observations have been made in marshes of Cape Cod (Howarth, 1979; Howarth and Teal, 1980). The morphology of the $\mathrm{FeS}_{2}$ formed is both framboidal and single crystalline particles (Luther et al, 1982). The principal difference between other reducing marine systems and the Great Marsh is that Great Marsh is apparently more oxidizing because of plant activity in the upper zone $(0-15 \mathrm{~cm})$ in the spring and summer, and more reducing during late Fall in the absence of active plant growth. Low $\mathrm{pH}$ values (3.5-6), excess sulfate (up to 60 $\mathrm{mM})$, low alkalinity (0-1 $\mathrm{mM})$ are common characteristics of this high marsh site in the upper zone during the spring and summer. In addition, thiols are observed in high micromolar concentrations. These chemical characteristics have not been observed in other reducing areas including the Framvaren fjord.

In this paper, we report further on the cycling of sulfur in the porewaters of Great Marsh, Delaware using larger data sets. In addition, we describe the seasonal coupling between iron and sulfur in the porewaters. The cycling of iron and sulfur is also shown to be highly dependent on tidal flushing and salinity regime in the marsh. Cutter and Velinsky (this volume) report on the solid 
phase inorganic sulfur speciation at our high salinity site in the Great Marsh, Delaware.

\section{EXPERIMENTAL}

Polarographic analysis of pore water samples for sulfur speciation was performed as described previously (Luther et al $1985,1986 a)$. To measure low levels of sulfur species $(<5 \mu M)$, differential pulse polarography was performed on samples. Samples were analyzed either at the porewater $\mathrm{pH}$ or in the $\mathrm{pH} 9.5$ base matrix which we use to measure $S(-2)$ sulfur as bisulfide and polysulfide, and $S(0)$ as polysulfide directly. Anhydrous sodium sulfide (Alfa) is used as a standard to determine $S(-2)$ and $S(0)$ in basic solution. Cysteine hydrochloride or glutathione (Sigma) are used to determine thiol content in basic solution. Thiosulfate standard solutions are purchased directly from Fisher Scientific. The method of standard additions is typically used to perform quantitative analysis on undiluted pore water samples. Samples diluted in base buffer are determined by a standard calibration curve in base buffer. Precision is typically $\pm 5 \%$ and frequently $\pm 1 \%$ or less.

Iron concentrations were determined by the use of the iron (II) chelating agent, ferrozine, as described by Stookey (1970). Chloride was determined by an argentometric Mohr titration. Sulfate was analyzed by the standard barium sulfate gravimetric technique. The $\mathrm{pH}$ was measured potentiometrically.

Our most recent data regarding the polarographic wave which we attributed to thiols (Luther et al, 1986b) indicate that it is 
composed of iron (II) organic complexes which contain thiols. These complexes may be of high molecular weight and of biological origin. They may be related to iron-sulfur proteins such as ferredoxins or rubredoxins (Thomson, 1985). Recently, Bonomi et al (1985) and Stevens and Kurtz (1985) in laboratory studies have shown that iron sulfur clusters can form in aqueous solution with $\mathrm{pH}$ values ranging from 4.5 to 10.5 . In some pore water samples at natural pH, and using linear sweep voltammetry (LSV) at a hanging mercury drop electrode, we have noticed that the thiosulfate wave $\left(E_{p}=-0.13 \mathrm{~V}\right)$ decreases and a new wave $\left(E_{p}=-0.42 \mathrm{~V}\right)$ increases on purging with argon. Thiosulfate can incorporate its terminal sulfur into an iron sulfur cluster, which may be responsible for this new wave, such as $\left[\mathrm{Fe}_{4} \mathrm{~S}_{4}(\mathrm{SR})_{4}\right]^{2-}$ (Bonomi et al, 1985). Thus, "iron thiolates" may be a more accurate description of what we, for simplicity, will continue to call "thiols". Further work is needed to elucidate the exact nature of the compound(s) responsible for our polarographic thiol data.

\section{FIELD LOCATION}

Figure 1 shows Great Marsh, Delaware and the location of the three sites for the sampling in this study. Site 1 is a high salinity site (25-30 ppt $\left.\mathrm{Cl}^{-}\right)$whereas sites 2 and 3 are medium $(6.5$ to $\left.12.1 \mathrm{ppt} \mathrm{Cl}^{-}\right)$and $10 \mathrm{w}\left(0-8.8 \mathrm{ppt} \mathrm{Cl}^{-}\right)$salinity respectively. Two companion creek bank locations were utilized; one (A) for the multiple salinity comparison near the confluence of two creeks, the second (B) next to a mosquito ditch some thirty meters up creek. A third location at site 1 , which is removed some 5 meters from the 
creek bank than B, has been well documented (Boulegue et al, 1982, Lord and Church, 1983; Luther et al, 1986b) as a location having extensive oxidizing conditions in the upper zone $(0-15 \mathrm{~cm})$ during times of high plant productivity. Site 1 undergoes extensive evapotranspiration during the summer, and it is flooded only for three to five days a month during the spring tide. This area is dominated by the short form of the cordgrass Spartina alterniflora. The tall form of the cordgrass is observed predominantly within $0.5 \mathrm{~m}$ of the creek bank. Most of the cores for our data were taken in the short form unless otherwise indicated in Table 1.

Sediment cores were taken hermetically by driving one meter lengths of $5.6 \mathrm{~cm}$ i.d. cellulose-acetate-butyrate core liner into the marsh. The liner was sealed at the sediment interface with a piston, withdrawn, capped and returned immediately to the laboratory. The cores were extruded at once and sectioned into 2$3 \mathrm{~cm}$ intervals under a nitrogen atmosphere in a glove box. Pore waters were expressed through $0.40 \mu \mathrm{m}$ Nuclepore membrane filters using pneumatic squeezers (Reeburgh, 1967). Approximately fifteen milliliters of porewater were collected for subsequent analysis. RESULTS

High Salinity Site

Table 1 shows the data obtained for field samplings in 1985 and 1986. The principal feature of this marsh site is the apparently strong oxidizing conditions in the $0-15 \mathrm{~cm}$ zone during growing seasons as evidenced by low porewater $\mathrm{pH}, \mathrm{S}(-2)$ sulfur and high excess sulfate values. Below this zone is the sulfate reducing 
zone. Oxidation of sulfide and sulfide minerals in the upper zone is responsible for these conditions. Low or zero alkalinity values are routinely detected in the upper oxidized zone with progressively increasing alkalinity values towards the lower zone due to increased sulfate reduction with depth in the soil (Lord and Church 1983). The oxidation of sulfide minerals, particularly $\mathrm{FeS}_{2}$, has been shown to be an important process in salt marsh soils by several workers (Giblin and Howarth, 1984; Howarth and Teal, 1979; Boulegue et al, 1982; Lord and Church, 1983; Luther et al, 1982; Luther et a1, 1986b). The data for total iron is given in Table 1. Addition of ferrozine directly (without a reducing agent) to the porewaters from the June sampling indicated that the dissolved iron is present abundantly as $\mathrm{Fe}(\mathrm{II})$. However, our January 1987 samples show only $\mathrm{Fe}$ (III) in the porewaters. This is the only set of porewaters for which Fe (II) and Fe (III) were quantitatively speciated. The Fe (III) is likely colloidal material passing through the $0.40 \mu \mathrm{m}$ filter. Such seasonal iron cycles are consistent with previous work in this marsh (Lord and Church, 1983) and elsewhere (Giblin and Howarth, 1984; Giblin et al, 1986.)

The release of $\mathrm{Pe}(\mathrm{II})$ to the porewater, low $\mathrm{pH}$, low alkalinity and high excess sulfate in the summer are apparently coupled to the formation of thiols in the upper zone of Great Marsh. Evidently, thiols are present in near $\mathrm{mM}$ concentrations under oxidizing conditions whereas inorganic sulfide is present under reducing conditions. The presence of thiols and $\mathrm{Fe}$ (II) in the same porewater sample under apparent oxidizing conditions allows for iron-thiol 
complexes which would help maintain the iron as $\mathrm{Fe}$ (II) for the subsequent formation of pyrite and perhaps the assimilation of iron (II) by Spartina alterniflora which is known to have high iron requirements (Adams, 1963; Waisel, 1972).

Thiosulfate and polysulfides (intermediate oxidation state sulfur compounds) are also present in the porewaters of Great Marsh. These species are intermediates in sulfide oxidation (Chen and Morris, 1972) and pyrite oxidation (Goldhaber, 1983; Moses et al, 1987) to sulfate. Thiosulfate can be important to the formation of thiols (Roy and Trudinger, 1970) and iron sulfur protein clusters (Bonomi et al, 1985). Polysulfides are important precursors to pyrite formation (Rickard, 1975). The zone of maximum polysulfide levels corresponds to the lower zone of increased pyrite levels in the soils (Cutter and Velinsky, this volume).

The data presented show that the cycling of sulfur in this high salinity site is coupled to iron cycling and seasonal plant productivity. The production of thiols is proposed to be related to pyrite oxidation in the upper zone. To our knowledge, no one has shown that pyrite oxidation depends on oxic ventilation of surface sediments as promoted by tidal flushing-a short term event. Figure 2A, B and C show the thiol, iron and pyrite data respectively for the period before and after the spring flood tide in June 1986. The data show that iron, as Fe(II), and thiol concentrations can increase dramatically after the flooding event and that pyrite concentrations in the salt marsh soils decrease. Because dissolved iron content is low in the incoming tidal water, the increase in 
iron and thiol concentrations after the flood could only come from $\mathrm{FeS}_{2}$ oxidation. The rate of this oxidation is extremely fast (less than the six days between our samplings) in accord with previous observations by Boulegue et al (1982) and lends support to the hypotheses of Howarth and coworkers (Howarth and Tea1,1980; Howarth et al 1983; Howarth, 1984) on the potential importance of pyrite oxidation to energy flow in a salt marsh ecosystem.

\section{Summer comparison at different salinity sites}

Figures $3 \mathrm{~A}$ and $\mathrm{B}$ show the $\mathrm{pH}$ and sulfate trends for the three salinity regimes sampled in Great Marsh. This data indicates that all three sites show oxidizing characteristics (low $\mathrm{pH}$, excess sulfate) in the upper zone which contains active roots. Thiosulfate and polysulfides, $S(0)$, are present at all sites and salinity regimes. The relative oxidizing potential based on $\mathrm{pH}$ and excess sulfate levels follows the trend; high salinity site $>$ medium salinity site > low salinity site. The low and medium sites also have lower porewater iron and thiol concentrations as shown in Table I. These observations are consistent with a sulfide oxidation process which is abated when less marine oxidized material (e.g. sulfate) is available for reactions at lower salinities. We have also observed such oxidizing characteristics and thiols in a medium salinity marsh in the Great Sippewisset, Cape Cod, Massachusetts. In the western part of that marsh (August 15, 1985), we measured excess sulfate $(+13.7 \mathrm{mM}), \mathrm{pH}(3.64)$ and thiols $(40 \mu \mathrm{M})$ in one core 
at a depth of $2-7 \mathrm{~cm}$. These data are consistent with pyrite oxidation occurring in the active root zone. It is important to note that the Cape Cod sample was taken in a section of that marsh which is not regularly flooded.

\section{Vegetated versus unvegetated high salinity comparison}

We also analyzed a core from a salt pan (an unvegetated location) which contained dead root material. This core was taken after the flood period in June and showed significant differences from the vegetated core taken after the flood tide. Table II shows $\mathrm{pH}$, excess sulfate, iron $\mathrm{S}(-2)$ and thiol concentrations for these two cores. The unvegetated location still shows at the surface some oxidizing conditions on the basis of excess sulfate concentrations. This observation is similar to that of Casey and Lasaga (1987) in a Virginia unvegetated panne. However, sulfide concentrations are significantly higher in the upper zone showing that sulfate reduction is occurring and is now the predominant process in the unvegetated site. The vegetated site shows negligible sulfide levels, lower $\mathrm{pH}$, and higher iron and thiol content than the unvegetated site. We conclude that the vegetated site exhibits more oxidizing conditions resulting in the oxidation of pyrite whereas the unvegetated site is more reducing. 


\section{DISCUSSION}

The data presented show that high salt marsh sediments have significant oxidizing capacity for inorganic sulfide as a result of several factors. These factors include significant plant production coupled with evapotranspiration or water uptake by roots (Dacey and Howes, 1984). The oxidizing capacity of salt marsh soils by Spartina results in a positive feedback loop which allows for better plant productivity (Howes et al, 1981). Spartina has also been shown to have the capacity to oxidize and uptake dissolved sulfide (Carlson and Forrest, 1982; Fry et al 1982). The oxidation is believed to be enzymatic.

Our data and that of other workers (Giblin and Howarth, 1984;

Giblin et al, 1986) also show that iron sulfides principally as $\mathrm{FeS}_{2}$, are oxidized in salt marsh sediments by the growth of Spartina. In high salt marshes with medium to high salinity, thiols are apparently produced as well. The production of thiols is directly tied to pyrite oxidation or turnover (Luther et al, 1986b). Figure 2 shows the general relation of increased thiol content with increased iron levels in the porewaters after the June flood and the effect of tidal influence on decreasing pyrite concentrations in the soils. These soluble iron data in Great Marsh, Delaware are similar to those of Lord (1980) but are higher than other reports for salt marshes. Adams (1963) reports iron levels up to $500 \mu \mathrm{M}$ in a North Carolina salt marsh, and Giblin and Howarth (1984) report that iron levels reach a high of $60 \mu \mathrm{M}$ in 
Great Sippewissett Marsh, Cape Cod. The latter report is more than one order of magnitude lower than our observations in Delaware. Thiol concentrations in the porewaters of Great Sippewissett are also less by the same order of magnitude or are not detectable. These differences suggest that there is a fundamental link between the iron and sulfur cycles and the health of the plants as suggested by other workers (Giblin and Howarth, 1984; King et al, 1982). It is well known that plants cannot tolerate high concentrations of metals (Grill et al, 1985). Iron concentrations at the millimolar level might be toxic to Spartina. However, the addition of dissolved iron to salt marsh sediments does not always have a measurable effect on grass growth (Giblin et al, 1980; Haines and Dunn, 1976). As commonly observed in biochemical processes when thiols are present, iron will be kept in the reduced state, as $\mathrm{Fe}(\mathrm{II})$. Also, iron-thiolate complexes may be important to the health of plants for several reasons. Iron (II) assimilation by plants for biological processes is possible (Waisel, 1972). In addition, the eventual precipitation of $\mathrm{FeS}_{2}$ should be facile when the necessary sulfur reactants, sulfides and polysulfides, result from sulfate reduction. Iron-thiolate complexes might thus serve to mitigate against the effects of iron toxicity to plants and aid the growth of plants.

The high concentrations of iron (II) in porewaters from the upper zone $(0-15 \mathrm{~cm})$ during the summer indicate that $\mathrm{FeS}_{2}$ oxidation or turnover is an important process. Sulfate ion is the major dissolved sulfur species. The apparent high levels of sulfate, 
iron (II) and thiols indicate an oxidation zone (high excess sulfate) or a mild reducing zone (high Fe (II) and thiol levels) sensitive to a variety of physical, biological and chemical factors.

To quantify these observations, we decided to calculate an apparent pE from the $\mathrm{FeS}_{2}, \mathrm{Fe}(\mathrm{II})$ and sulfate couple ( $\mathrm{FeS}_{2}$ oxidation or hydrolysis) because these are the primary redox species in the upper zone. The calculated $\mathrm{pE}$ should reflect the relative redox condition of the zone. The reaction is given as equation (1) which represents the equilibium reaction.

(1) $\mathrm{FeS}_{2}+8 \mathrm{H}_{2} \mathrm{O} \rightarrow \mathrm{Fe}^{2+}+2 \mathrm{SO}_{4}{ }^{2-}+16 \mathrm{H}^{+}+14 \mathrm{e}^{-}$

Ion activites \{\} were then calculated with the aid of the computer program, PHREEQE (Pankhurst et al, 1980) according to equation (2).

(2) $\log \frac{\left[\mathrm{FeS}_{2}\right]}{\left\{\mathrm{Fe}^{2+}\right\}}=2 \log \left\{\mathrm{SO}_{4}{ }^{2-}\right\}-16 \mathrm{pH}-14 \mathrm{pE}+86.8$

The calculated $\mathrm{pE}$ values for the high salinity site in June 1986 (before the flood) are $+0.624(2.5-5 \mathrm{~cm})$, and $+0.316(5-7.5 \mathrm{~cm}$ ). For the same site after the flood, $\mathrm{pE}$ values are $-2.07(0-2.5$ $\mathrm{cm}),-0.133(2.5-5 \mathrm{~cm})$ and $-1.60(7.5-10 \mathrm{~cm})$. These calculations suggest that the upper zone is poised between mild oxidizing and reducing conditions. In fact, the zone is slightly reducing after the flood tide and slightly oxidizing before the flood. The reducing nature of the porewaters after the June flood tide is due to iron (II) concentrations increasing over an order 
of magnitude and sulfate concentrations decreasing by only one half. The redox condition is not likely to be related to only chemical processes. At the low $\mathrm{pH}$ values of the upper zone (particularly 2.5 to $7.5 \mathrm{~cm}$ ), it is likely that bacterial processes are responsible for the rapid turnover (Ehrlich, 1981). In support of this concept the rapid jump in $\mathrm{Fe}$ (II) and thiol concentrations before and after the high tide occurred in six days (or less). To show the significance of this oxidation, we performed the following calculation. The increase in dissolved Fe (II) content (before and after the flooding) for the $2.5-5.0 \mathrm{~cm}$ section is 840 $\mu$ M. Assuming a density of 1.8 for marsh muds (Lord, 1980), we estimate that 0.467 moles $(g \mathrm{dry} w t)^{-1}$ of iron were released to the pore waters by dissolution or oxidation of iron minerals. For this section, 36.4 umole $(\mathrm{g} \text { dry wt) })^{-1}$ of pyrite ( $15 \%$ of the total solid sulfur) were oxidized in six days or less. This represents nearly one hundred times less iron released to the porewaters based upon pyrite oxidation. Undoubtably, the iron lost must precipitate as authigenic iron phases. Two possibilities include high molecular weight iron organic solids and iron (III) oxyhydroxides which are among the likely chemical reactants oxidizing the pyrite (Singer and Stumm, 1970 and Luther, 1987). Solid iron oxide phases are present in crystalline and amorphous forms (Luther et al, 1982), and at relatively abundant levels of $0.5-4.07$ by weight (Cutter and Velinsky, This volume; Lord, 1980). The maximum increase in thiol production, assuming one sulfur from pyrite is converted to a thiol, is $66 \mu \mathrm{M}$. In fact, the increase we measured was $112 \mu \mathrm{M}$. 
The oxidation of pyrite does not necessarily require molecular oxygen (Singer and Stumm, 1970; Nordstrom, 1982; Luther 1987). However, recent work by Morris and Whiting (1985) indicates that substantial quantities of dissolved $\mathrm{O}_{2}$ may be drawn into some salt marsh sediments by evapotranspiration. After tidal flooding the concentration of $\mathrm{O}_{2}$ is greatly decreased and the concentration of $\mathrm{CH}_{4}$ is increased in gas bubbles which evolve. Thus, $\mathrm{O}_{2}$ may contribute somewhat to the pyrite turnover process. However, the amount of dissolved $\mathrm{O}_{2}$ change cannot account for the magnitude of pyrite oxidation which we observed. Other oxidants such as $\mathrm{MnO}_{2}$ and Fe (III), via microbial catalysis of $\mathrm{Fe}$ (II) oxidation at low $\mathrm{pH}$, can affect the speed and ease of pyrite cycling in salt marsh sediments. In support of this, Singer and Strumm (1970) have shown that $\mathrm{Fe}$ (III) is the major oxidant of $\mathrm{FeS}_{2}$ in acid mine areas and that oxygen initiates the oxidation.

During less productive seasons, sulfate reduction becomes the predominant biogeochemical process. However, at winter temperatures the rate of sulfate reduction decreases dramatically as evidenced by lower positive or negative $\Delta \mathrm{SO}_{4}{ }^{2-}$ levels. Iron is gradually precipitated during the cooler seasons (Cutter and Velinsky, 1987; Lord, 1980).

\section{CONCLUSION}

We sampled to show the seasonal cycling of iron and sulfur in a high salt marsh. In addition, we also sampled before and after the monthly spring tide during the sumer in vegetated and unvegetated sites in order to show the affects of oxic ventilation 
of surface sediments on the iron and sulfur cycles. The data is consistent with a process showing both pyrite formation and turnover in more productive seasons. Pyrite turnover can be rapid and exceeds the rate of pyrite formation in the summer. Pyrite is a likely starting material for iron (II) complexes and thiol production in marsh porewaters. However, other thiol producing reactions can occur in salt marsh soils as we previously outlined (Luther et al, 1986b). The turnover of pyrite to a thiol or ironthiolate complexes occurs via an oxidation process. Excess sulfate, low $\mathrm{pH}$ and high iron concentrations are observed and are consistent with such a pyrite oxidation process. Solid authigenic iron phases are likely the more important iron products of pyrite oxidation. We conclude from our data that pyrite formation and its chemosynthetic recycling via iron (II) complexes and thiols may be an important biogeochemical process. As such, pyrite recycling may consist of an oxidation reaction promoted via microbial organisms. Because salt marshes contain much labile and reactive organic material, the pyrite recycling links the organic and inorganic sulfur pools and aids in the cycling of energy and material in wetlands. 


\section{ACKNOWLEDGEMENTS}

We thank J. Scudlark, T. Ferdelman, M. Montgomery, D. Powell, C. Traynor, J. Ortega and M. Cosman for aid in field sampling and porewater analysis. G. Cutter and D. Velinsky graciously provided the pyrite measurements and $W$. Ullman provided the ion activity calculations with the program PHREEQE. This work was supported primarily by NSF grants OCE-8696121 to G. W. Luther and OCE-8541757 to T. M. Church from the National Science Foundation. The salinity and tidal summer comparisons were part of the Wetlands Project of the NASA Global Biology Program (grant NAG -1-682). The Great Sippewissett Marsh study was supported by a grant from the Petroleum Research Fund administered by the American Chemical Society. 


\section{REFERENCES}

Adams, D.A. 1963. Factors influencing vascular plant zonation in North Carolina salt marshes. Ecology 44: 445-456.

Bonomi, F., M.T. Werth and D.M. Kurtz. 1985. Assembly of $\left[\mathrm{Fe}_{n} \mathrm{~S}_{n}(\mathrm{SR})_{4}\right]^{2}-(\mathrm{n}=2,4)$ in aqueous media from iron salts, thiols, sulfur, sulfide, or thiosulfate plus rhodanese. Inorg. Chem. 24: 4331-4335

Boulegue, J., C.J. Lord, and T.M. Church. 1982. Sulfur speciation and associated trace metals $(\mathrm{Fe}, \mathrm{Cu}$ ) in the porewaters of Great Marsh, Delaware. Geochim. Cosmochim. Acta 46: 453464.

Carlson, P.R. and J. Forrest. 1982. Uptake of dissolved sulfide by Spartina alterniflora; evidence from natural sulfur isotope abundance ratios. Science Vo1. 216, p. 633-635.

Casey, W.. and A.C. Lasaga. 1987. Modeling solute transport and sulfate reduction in marsh sediments. Geochim. Cosmochim. Acta., Vol. 51, 1109-1120.

Cutter, G.A. and D.J. Velinsky. Sulfur diagenesis in a coastal salt marsh. Mar. Chem. (this volume).

Dacey, J.W.H. and B.L. Howes, 1984. Water Uptake by roots controls water table movement and sediment oxidation in short Spartina marsh. Science. Vo1. 224. p. 487-489.

Ehrlich, H.L., Geomicrobiology, Marcel Dekker, New York, 1981. 
Fry, B., R.S. Scanlan, J.K. Winters, and P.L. Parker. 1982.

Sulphur uptake by salt grasses, mangroves and seagrasses in anaerobic sediments. Geochim. Cosmochim. Acta, Vol. 46, $1121-1124$

Giblin, A.E., A. Bourg, I. Valiela and J.M. Teal. 1980. Uptake and losses of heavy metals in sewage sludge by a New England salt marsh. Am. J. Bot. 67: 1059-1068.

Giblin, A.E., and R.W. Howarth. 1984. Porewater evidence for a dynamic sedimentary iron cycle in salt marshes. Limnol. Oceanogr. 29: 47-63.

Giblin, A.E., G.W. Luther, III and I. Valiela, 1986. Trace metal solubility in salt marsh sediments contaminated with sewage sludge. Est. Coastal Shelf Sci., Vol. 23, 477-498.

Goldhaber, M.B. 1983. Experimental study of metastable sulfur oxyanion formation during pyrite oxidation at $\mathrm{pH}$ 6-9 and $30^{\circ} \mathrm{C}$ Am. J. Sci. 283: 193-217.

Grill, E., E.-L. Winnacker and M.H. Zank. 1985. Phytochelatins: The principal heavy-metal complexing peptides of higher plants. Science Vol. 230, p. 674-676.

Haines, B. and E. Dunn. 1976. Growth and resource allocation responses of $\underline{\mathrm{S}}$ alterniflor to three levels of $\mathrm{NH}_{4}-\mathrm{N}, \mathrm{Fe}$, and $\mathrm{NaCl}$ in solution culture. Bot. Gaz. 137: 224-230.

Howarth, R.W. 1979. Pyrite: Its rapid formation in a salt marsh and its importance in ecosystem metabolism. Science 203: 49-51. 
Howarth, R.W. 1984. The ecological significance of sulfur in the energy dynamics of salt marsh and coastal marine sediments. Biogeochemistry 1: 5-27.

Howarth, R.W., and J.M. Teal. 1979. Sulfate reduction in a New England salt marsh. Limnol. Oceanogr. 24: 999-1013.

Howarth, R.W., J.M. Teal. 1980. Energy flow in a salt marsh ecosystem: The role of reduced inorganic sulfur compounds. Am. Nat. 116: 862-872.

Howes, B.L., R.W. Howarth, J.M. Teal and I. Valiella. 1981. Oxidation-reduction potentials in a salt marsh: Spatial patterns and interactions with primary production. Limnol. Oceanogr. 26: $350-360$.

King, G.M., B.L. Howes and J.W.H. Dacey. 1985. Short-term endproducts of sulfate reduction in a salt marsh: Formation of acid volatile sulfides, elemental sulfur, and pyrite. Geochim. Cosmochim. Acta, Vo.1. 49, p. 1561-1566.

King, G. M., M.L. Klug, R. G. Wiegert and A.G. Chalmers. 1982. Relation of soil water movement and sulfide concentration of Spartina alterniflora production in a Georgia salt marsh. Science 218: 61-63.

Lord, C.J., III. 1980. The chemistry and cycling of iron, manganese and sulfur in salt marsh sediments, Ph.D. dissertation, University of Delaware.

Lord, C.J., III and T.M. Church. 1983. The geochemistry of salt marshes: Sedimentary ion diffusion, sulfate reduction, and pyritization. Geochim. Cosmochim. Acta 47: 1381-1391. 
Luther, G.W. III. 1987. Pyrite oxidation and reduction: molecular orbital theory considerations, submitted.

Luther, G.W., III, T.M. Church, A. Giblin and R.W. Howarth. 1986a. Speciation of dissolved sulfur in salt marshes by polarographic methods. In ACS Symposium Series, Organic Marine Geochemistry, M. Sohn, ed. Vo1. 305, p. 339-355.

Luther, G.W., III, T.M. Church, J.R. Scudlark and M. Cosman. 1986b. Inorganic and Organic sulfur cycling in salt-marsh porewaters. Science 232: 746-749.

Luther, G.W., III, A. Giblin, R.W. Howarth, and R.A. Ryans. 1982. Pyrite and oxidized iron mineral phases formed from pyrite oxidation in salt marsh and estuarine sediments. Geochim. Cosmochim. Acta 46: 2665-2669.

Luther, G.W., III, A.E. Giblin and R. Varsolona. 1985. Polarographic analysis of sulfur species in marine porewaters. Limnol. Oceanogr. 30: 727-736.

Morris, J.T. and G.J. Whiting. 1985. Gas advection in sediments of a South Carolina salt marsh. Mar. Ecol. Prog. Ser. Vol. 27: $187-194$.

Moses, C.O., D.K. Nordstrom, J.S. Herman and A.L. Mills. 1987. Aqueous pyrite oxidation by dissolved oxygen and by ferric iron. Geochim. Cosmochim. Acta (in press).

Nordstrom, D.K. 1982. Aqueous pyrite oxidation and the consequent formation of secondary iron minerals, in Acid Sulfate Weathering, T.A. Kittick et al, eds., Soil Science Society of America, Madison, Wi, pp. 37-56. 
Pankhurst, D.L., D.C. Thorstenson and L.N. Plummer. 1980. PHREEQE, Water Resources Investigations 80-96, United States Geological Survey, Denver.

Reeburgh, W.S. 1967. An improved interstitial water sampler.

Limnol. Oceanogr. 12: 163-165.

Rickard, D.T. 1975. Kinetics and mechanism of pyrite formation at low temperatures. Am. J. Sci. 275: 636-652.

Roy, A.B. and P.A. Trudinger. 1970. The Biochemistry of Inorganic Compounds of Sulfur, Cambridge University Press, London.

Stevens, W.C. and D.M. Kurtz. 1985. Assemby of $\left[\mathrm{Fe}_{n} \mathrm{~S}_{n}(\mathrm{SPh})_{4}\right]^{2-}$ $(n=2,4)$ and their iron-thiolate precursors in aqueous media Inorg. Chem. 24: 3444-3449.

Stookey, L.L. 1970. Ferrozine-a new spectrophotometric reagent for iron. Anal. Chem., 41: 143-146.

Thomson, A.J. 1985. in Metalloproteins, Part one: Metal proteins with redox roles, P.M. Harrison, Ed., Verlag Chemie, pp 79120.

Waisel, Y. 1972. Biology of Halophytes, Academic Press, New York. 
Table I. Pore water data for samples taken June 18, 1985 to January 1987. The data for $\Delta \mathrm{SO}_{4}$ is the $\mathrm{mM}$ change in sulfate relative to the seawater sulfate/chloride ratio. Positive signs indicate excesses (oxidation) and negative signs indicate depletion (reduction). NA and ND signify not analyzed and not detectable, respectively. Iron data is reported for total iron.

Table II. Pore water data from the vegetated and unvegetated cores taken after the spring flood in June 23, 1986 at the high salinity site. NA and ND signify not analyzed and not detectable, respectively. 
HIGH SALINITY (SITE 1B) JUNE 18, 1985 - BEFORE THE MONTHLY FLOOD

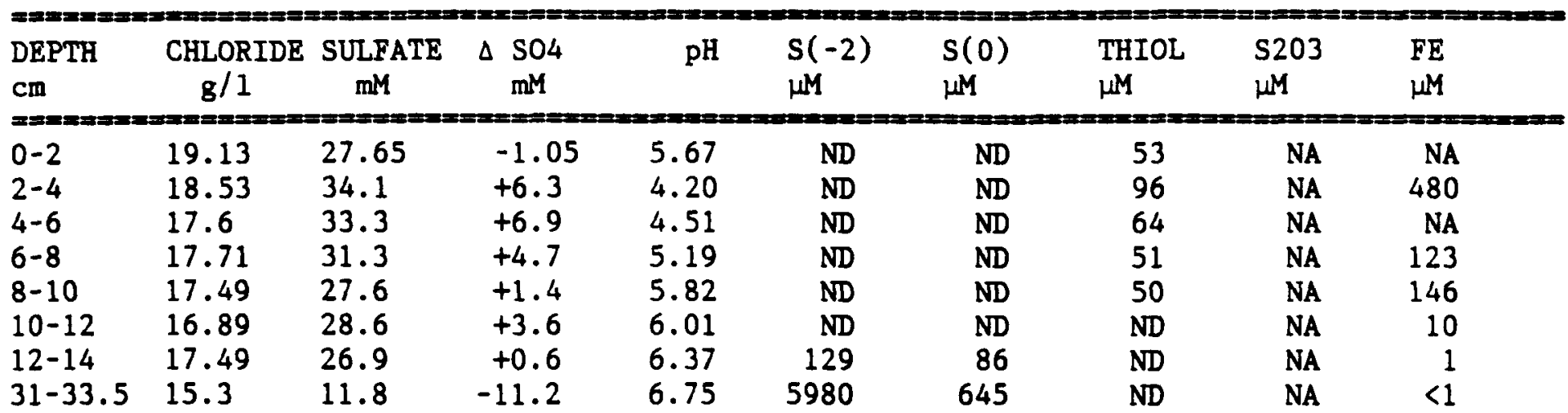

HIGH SALINITY (SITE 1B) DECEMBER 11, 1985 - TALL SPARTINA

\begin{tabular}{|c|c|c|c|c|c|}
\hline $\begin{array}{l}\text { DEPTH } \\
\mathrm{cm}\end{array}$ & $\begin{array}{ll}\text { CHLORIDE } & \text { SULFATE } \\
\mathrm{g} / 1 & \mathrm{mM}\end{array}$ & $\triangle \mathrm{mM}_{\mathrm{mM}} \mathrm{SO4}$ & $\mathrm{pH}$ & $\begin{array}{l}S(-2) \\
\mu M\end{array}$ & $\begin{array}{l}S(0) \\
\mu M\end{array}$ \\
\hline
\end{tabular}

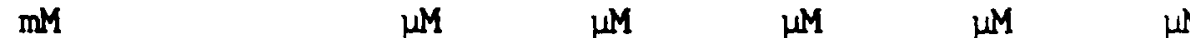

$\begin{array}{lllllllllc}0.2 .5 & 14.0 & 23.8 & +14.5 & 6.54 & \text { ND } & \text { ND } & \text { ND } & \text { ND } & 5 \\ 2.5-5 & 14.9 & 23.8 & +13.9 & 5.89 & \text { ND } & \text { ND } & \text { ND } & 1.05 & 7.5 \\ 5-7.5 & 15.8 & 27.0 & +16.5 & 6.06 & \text { ND } & \text { ND } & \text { ND } & 2.1 & 8 \\ 7.5-10 & 16.7 & 26.6 & +15.5 & 6.30 & \text { ND } & \text { ND } & \text { ND } & 1.92 & 19 \\ 10-12.5 & 18.2 & 23.6 & +11.5 & 6.51 & \text { ND } & \text { ND } & \text { ND } & \text { ND } & <1\end{array}$

HIGH SALINITY (SITE 1B) MARCH 27, 1986 - AFTER THE MONTHLY FLOOD

\begin{tabular}{|c|c|c|c|c|c|c|c|c|c|}
\hline $\begin{array}{l}\text { DEPTH } \\
\mathrm{cm}\end{array}$ & $\begin{array}{l}\text { CHLORIDE } \\
\mathrm{g} / 1\end{array}$ & $\begin{array}{l}\text { SULFATE } \\
\mathrm{mM}\end{array}$ & $\begin{array}{l}\Delta \mathrm{SO} 4 \\
\mathrm{mM}\end{array}$ & $\mathrm{pH}$ & $\begin{array}{l}S(-2) \\
\mu M\end{array}$ & $\begin{array}{l}S(0) \\
\mu M\end{array}$ & $\begin{array}{l}\text { THIOL } \\
\mu \mathrm{M}\end{array}$ & $\begin{array}{l}S 203 \\
\mu \mathrm{M}\end{array}$ & $\begin{array}{l}F E \\
\mu M\end{array}$ \\
\hline $\begin{array}{l}0-3 \\
0-3 \\
3-5.5 \\
6-8.5 \\
8.5-11 \\
11-14 \\
14-16 \\
21-24\end{array}$ & $\begin{array}{l}47.60 \\
16.85 \\
16.23 \\
16.95 \\
17.04 \\
17.71 \\
17.85\end{array}$ & $\begin{array}{l}131.2 \\
42.7 \\
12.4 \\
16.0 \\
9.3 \\
3.8 \\
10.6\end{array}$ & $\begin{array}{l}+99.5 \\
+31.5 \\
+1.6 \\
+4.7 \\
-2.0 \\
-8.0 \\
-1.3\end{array}$ & $\begin{array}{l}6.88 \\
4.55 \\
7.35 \\
7.47 \\
7.38 \\
7.33 \\
6.99\end{array}$ & $\begin{array}{r}\mathrm{ND} \\
\mathrm{ND} \\
\mathrm{ND} \\
\mathrm{ND} \\
\mathrm{ND} \\
1070 \\
2380\end{array}$ & $\begin{array}{c}\text { ND } \\
\text { ND } \\
\text { ND } \\
\text { ND } \\
\text { ND } \\
66.2 \\
160\end{array}$ & $\begin{array}{r}\text { ND } \\
\text { ND } \\
4 \\
\text { ND } \\
24 \\
\text { ND } \\
\text { ND }\end{array}$ & $\begin{array}{r}\text { ND } \\
\text { ND } \\
46.9 \\
14.1 \\
79.1 \\
116.4 \\
75.2\end{array}$ & $\begin{array}{l}\text { NA } \\
\text { NA } \\
\text { NA } \\
\text { NA } \\
\text { NA } \\
\text { NA } \\
\text { NA }\end{array}$ \\
\hline
\end{tabular}


HIGH SALINITY (SITE 1A) JUNE 17, 1986-BEFORE THE MONTHLY FLOOD

\begin{tabular}{|c|c|c|c|c|c|c|c|c|c|}
\hline $\begin{array}{l}\text { DEPTH } \\
\mathrm{cm}\end{array}$ & $\begin{array}{l}\text { CHLORIDE } \\
8 / 1\end{array}$ & $\begin{array}{l}\text { SULFATE } \\
\mathrm{mM}\end{array}$ & $\triangle \underset{\mathrm{mM}}{\mathrm{SO}}$ & $\mathrm{pH}$ & $\begin{array}{l}S(-2) \\
\mu M\end{array}$ & $\begin{array}{l}S(0) \\
\mu M\end{array}$ & $\begin{array}{l}\text { THIOL } \\
\mu M\end{array}$ & $\begin{array}{l}S 203 \\
\mu \mathrm{M}\end{array}$ & $\begin{array}{l}F E \\
\mu M\end{array}$ \\
\hline $\begin{array}{l}0-2 \cdot 5 \\
2 \cdot 5-5 \\
5-7.5 \\
7.5-10 \\
10-12 \cdot 5 \\
12 \cdot 5-15 \\
15-17 \cdot 5\end{array}$ & $\begin{array}{r}30.5 \\
26.6 \\
25.4 \\
\text { NA } \\
22.1 \\
21.2 \\
21.2\end{array}$ & $\begin{array}{r}65.2 \\
70.0 \\
59.3 \\
\text { NA } \\
22.4 \\
12.0 \\
9.9\end{array}$ & $\begin{array}{c}+44.9 \\
+52.3 \\
+42.4 \\
\text { NA } \\
+7.7 \\
-2.1 \\
-4.2\end{array}$ & $\begin{array}{l}5.39 \\
4.38 \\
4.64 \\
6.39 \\
6.98 \\
7.22 \\
7.41\end{array}$ & $\begin{array}{r}0.2 \\
0.4 \\
4.9 \\
\text { ND } \\
47 \\
253 \\
853\end{array}$ & $\begin{array}{l}\text { ND } \\
\text { ND } \\
\text { ND } \\
\text { ND } \\
28 \\
34 \\
39\end{array}$ & $\begin{array}{r}0.5 \\
8.4 \\
36 \\
\text { ND } \\
\text { ND } \\
\text { ND } \\
\text { ND }\end{array}$ & $\begin{array}{r}\text { ND } \\
\text { ND } \\
4.2 \\
\text { NA } \\
16 \\
16 \\
\text { NA }\end{array}$ & $\begin{array}{r}\text { NA } \\
1150 \\
1000 \\
3 \\
1 \\
1 \\
<1\end{array}$ \\
\hline
\end{tabular}

HIGH SALINITY (SITE 1A) JUNE 23, 1986-AFTER THE MONTHLY FLOOD

\begin{tabular}{|c|c|c|c|c|c|c|c|c|c|}
\hline $\begin{array}{l}\text { DEPTH } \\
\text { mc }\end{array}$ & $\begin{array}{l}\text { CHLORIDE } \\
8 / 1\end{array}$ & $\begin{array}{l}\text { SULFATE } \\
\mathrm{mM}\end{array}$ & $\underset{\mathrm{mM}}{\Delta \mathrm{SO} 4}$ & $\mathrm{pH}$ & $\begin{array}{l}S(-2) \\
\mu M\end{array}$ & $\begin{array}{l}S(0) \\
\mu M\end{array}$ & $\begin{array}{l}\text { THIOL } \\
\mu \mathrm{M}\end{array}$ & $\begin{array}{l}\mathrm{S} 203 \\
\mu \mathrm{M}\end{array}$ & $\begin{array}{l}\mathrm{FE} \\
\mu \mathrm{M}\end{array}$ \\
\hline $\begin{array}{l}0-2.5 \\
2.5-5 \\
5-7.5 \\
7.5-10\end{array}$ & $\begin{array}{l}21.4 \\
26.1 \\
27.2 \\
26.8\end{array}$ & $\begin{array}{l}30.3 \\
49.8 \\
53.6 \\
43.7\end{array}$ & $\begin{array}{l}+16.02 \\
+32.39 \\
+35.44 \\
+26.86\end{array}$ & $\begin{array}{l}6.59 \\
5.04 \\
4.82 \\
6.22\end{array}$ & $\begin{array}{l}\text { ND } \\
\text { ND } \\
\text { ND } \\
\text { ND }\end{array}$ & $\begin{array}{l}\text { ND } \\
\text { ND } \\
\text { ND } \\
\text { ND }\end{array}$ & $\begin{array}{l}133 \\
121 \\
891 \\
9 . .4\end{array}$ & $\begin{array}{r}\text { NA } \\
13.5 \\
\text { ND } \\
\text { ND }\end{array}$ & $\begin{array}{r}23 \\
1900 \\
\text { NA } \\
67\end{array}$ \\
\hline
\end{tabular}

LOW SALINITY (SITE 3) JUNE 18, 1986 - BEFORE THE MONTHLY FLOOD

\begin{tabular}{|c|c|c|c|c|c|c|c|c|c|}
\hline $\begin{array}{c}\text { DEPTH } \\
\mathrm{cm}\end{array}$ & $\begin{array}{l}\text { CHLORIDE } \\
\mathbf{g} / \mathbf{1}\end{array}$ & $\begin{array}{l}\text { SULFATE } \\
\mathrm{mM}\end{array}$ & $\underset{\mathrm{mM}}{\Delta \mathrm{SO4}}$ & $\mathrm{pH}$ & $\begin{array}{l}S(-2) \\
\mu M\end{array}$ & $\begin{array}{l}S(0) \\
\mu M\end{array}$ & $\begin{array}{l}\text { THIOL } \\
\mu \mathrm{M}\end{array}$ & $\begin{array}{l}S 203 \\
\mu M\end{array}$ & $\begin{array}{l}F E \\
\mu M\end{array}$ \\
\hline $\begin{array}{l}0-2.5 \\
5-7.5 \\
7.5-10 \\
10-12.5 \\
12.5-15\end{array}$ & $\begin{array}{l}6.90 \\
6.60 \\
5.81 \\
5.38 \\
4.94\end{array}$ & $\begin{array}{l}8.76 \\
8.35 \\
5.66 \\
4.91 \\
3.62\end{array}$ & $\begin{array}{l}+4.16 \\
+3.95 \\
+1.78 \\
+1.32 \\
+0.33\end{array}$ & $\begin{array}{l}5.78 \\
6.04 \\
6.38 \\
6.54 \\
6.76\end{array}$ & $\begin{array}{l}2.8 \\
7.3 \\
12 \\
50 \\
184\end{array}$ & $\begin{array}{c}\mathrm{ND} \\
\mathrm{ND} \\
\mathrm{ND} \\
7.6 \\
26.2\end{array}$ & $\begin{array}{l}11 \\
\text { ND } \\
\text { ND } \\
\text { ND } \\
\text { ND }\end{array}$ & $\begin{array}{l}0.3 \\
31 \\
31 \\
23.2 \\
50.2\end{array}$ & $\begin{array}{l}1 \\
4 \\
\text { ND } \\
\text { ND } \\
2\end{array}$ \\
\hline
\end{tabular}

MEDIUM SALINITY (SITE 2) JUNE 18, 1986 - BEFORE THE MONTHLY FLOOD

\begin{tabular}{|c|c|c|c|c|c|c|c|c|c|}
\hline $\begin{array}{l}\text { DEPTH } \\
\mathrm{cm}\end{array}$ & $\begin{array}{l}\text { CHLORIDE } \\
\mathrm{g} / 1\end{array}$ & $\begin{array}{c}\text { SULFATE } \\
\mathrm{mM}\end{array}$ & $\underset{\mathrm{mM}}{\Delta \mathrm{SO}^{\mathrm{S}} 4}$ & $\mathrm{pH}$ & $\begin{array}{l}S(-2) \\
\mu M\end{array}$ & $\begin{array}{l}S(0) \\
\mu M\end{array}$ & $\begin{array}{l}\text { THIOL } \\
\mu \mathrm{M}\end{array}$ & $\begin{array}{l}S 203 \\
\mu M\end{array}$ & $\begin{array}{l}F E \\
\mu M\end{array}$ \\
\hline $\begin{array}{l}0-2.5 \\
2.5-5 \\
7.5-10 \\
10-12.5 \\
12.5-15\end{array}$ & $\begin{array}{l}12.13 \\
9.72 \\
7.95 \\
6.94 \\
6.73\end{array}$ & $\begin{array}{l}19.64 \\
14.33 \\
5.87 \\
2.59 \\
3.04\end{array}$ & $\begin{array}{l}+11.55 \\
+7.85 \\
+0.57 \\
-2.04 \\
-1.45\end{array}$ & $\begin{array}{l}5.5 \\
6 \\
7.07 \\
7.09 \\
6.87\end{array}$ & $\begin{array}{c}\text { ND } \\
1.4 \\
297 \\
404 \\
1720\end{array}$ & $\begin{array}{l}\text { ND } \\
\text { ND } \\
\text { ND } \\
7 \\
\text { ND }\end{array}$ & $\begin{array}{l}1 \\
\text { ND } \\
\text { ND } \\
\text { ND } \\
\text { ND }\end{array}$ & $\begin{array}{l}1.9 \\
3.3 \\
54.1 \\
95.1 \\
22.2\end{array}$ & $\begin{array}{r}18 \\
1 \\
<1 \\
4 \\
<1\end{array}$ \\
\hline
\end{tabular}


HIGH SALINITY (SITE 1B) SEPT.8, 1986 - TALL SPARTINA - AFTER THE MONTHLY FLOOD

\begin{tabular}{|c|c|c|c|c|c|c|c|c|c|}
\hline $\begin{array}{l}\text { DEPTH } \\
\mathrm{cm}\end{array}$ & $\begin{array}{l}\text { CHLORIDE } \\
\mathbf{g} / \mathbf{I}\end{array}$ & $\begin{array}{l}\text { SULFATE } \\
\mathrm{mM}\end{array}$ & $\underset{\mathrm{mM}}{\mathrm{SO}}$ & $\mathrm{pH}$ & $\begin{array}{l}S(-2) \\
\mu M\end{array}$ & $\begin{array}{l}S(0) \\
\mu M\end{array}$ & $\begin{array}{l}\text { THIOL } \\
\mu \mathrm{M}\end{array}$ & $\begin{array}{l}S 203 \\
\mu \mathrm{M}\end{array}$ & $\begin{array}{l}F E \\
\mu M\end{array}$ \\
\hline $\begin{array}{l}0-2 \\
2-4 \\
4-6 \\
6-8 \\
8-10 \\
10-12 \\
12-14 \\
14-17 \\
17-20 \\
28-30\end{array}$ & $\begin{array}{l}25.8 \\
26.0 \\
27.2 \\
27.3 \\
27.5 \\
28.4 \\
28.3 \\
27.4 \\
27.2 \\
24.5\end{array}$ & $\begin{array}{l}39.04 \\
36.98 \\
47.65 \\
45.31 \\
46.34 \\
41.69 \\
34.84 \\
31.32 \\
25.37 \\
15.00\end{array}$ & $\begin{array}{l}+21.8 \\
+19.7 \\
+29.6 \\
+27.1 \\
+28.0 \\
+22.8 \\
+15.9 \\
+13.0 \\
+7.3 \\
-1.3\end{array}$ & $\begin{array}{l}6.32 \\
6.23 \\
6.18 \\
6.01 \\
6.51 \\
6.7 \\
6.93 \\
7.06 \\
7.18 \\
7.2\end{array}$ & $\begin{array}{l}\mathrm{ND} \\
\mathrm{ND} \\
\mathrm{ND} \\
\mathrm{ND} \\
\mathrm{ND} \\
\mathrm{ND} \\
\mathrm{ND} \\
\mathrm{ND} \\
\mathrm{ND} \\
763\end{array}$ & $\begin{array}{l}\text { ND } \\
\text { ND } \\
\text { ND } \\
\text { ND } \\
\text { ND } \\
\text { ND } \\
\text { ND } \\
\text { ND } \\
\text { ND } \\
\text { ND }\end{array}$ & $\begin{array}{l}\text { ND } \\
\text { ND } \\
\text { ND } \\
\text { ND } \\
\text { ND } \\
\text { ND } \\
\text { ND } \\
\text { ND } \\
\text { ND } \\
\text { ND }\end{array}$ & $\begin{array}{l}\text { ND } \\
\text { ND } \\
\text { ND } \\
\text { ND } \\
\text { ND } \\
\text { ND } \\
\text { ND } \\
\text { ND } \\
\text { ND } \\
\text { ND }\end{array}$ & $\begin{array}{r}<1 \\
15 \\
139 \\
162 \\
73 \\
37 \\
14 \\
15 \\
10 \\
16\end{array}$ \\
\hline
\end{tabular}

HIGH SALINITY (SITE 1B) JAN. 9, 1987 - AFTER THE MONTHLY FLOOD

\begin{tabular}{|c|c|c|c|c|c|c|c|c|c|}
\hline $\begin{array}{l}\text { DEPTH } \\
\mathrm{cm}\end{array}$ & $\begin{array}{l}\text { CHLORIDE } \\
\mathbf{g} / \mathbf{1}\end{array}$ & $\begin{array}{l}\text { SULFATE } \\
\mathrm{mM}\end{array}$ & $\underset{\mathrm{mM}}{\Delta \mathrm{SO}}$ & $\mathrm{pH}$ & $\begin{array}{c}S(-2) \\
\mu M\end{array}$ & $\begin{array}{c}S(0) \\
\mu M\end{array}$ & $\begin{array}{l}\text { THIOL } \\
\mu \mathrm{M}\end{array}$ & $\begin{array}{c}S 203 \\
\mu \mathrm{M}\end{array}$ & $\begin{array}{l}\mathrm{FE} \\
\mu \mathrm{M}\end{array}$ \\
\hline $\begin{array}{l}0-2 \\
2-4 \\
4-6 \\
6-8 \\
8-10 \\
10-12 \cdot 5 \\
15-17.5 \\
20-22.5 \\
25-27.5 \\
30-32\end{array}$ & $\begin{array}{l}15.36 \\
16.85 \\
18.31 \\
21.36 \\
24.07 \\
24.00 \\
27.63 \\
28.04 \\
26.95 \\
26.04\end{array}$ & $\begin{array}{l}26.39 \\
12.98 \\
17.61 \\
18.64 \\
21.08 \\
24.55 \\
19.45 \\
12.9 \\
9.43 \\
6.90\end{array}$ & $\begin{array}{l}+16.14 \\
+1.74 \\
+5.40 \\
+4.39 \\
+5.03 \\
+8.54 \\
+1.02 \\
-1.02 \\
-8.55 \\
-10.47\end{array}$ & $\begin{array}{l}6.73 \\
6.52 \\
6.88 \\
6.83 \\
6.86 \\
6.86 \\
6.92 \\
6.92 \\
6.98 \\
7.05\end{array}$ & $\begin{array}{r}\text { ND } \\
\text { ND } \\
\text { ND } \\
\text { ND } \\
\text { ND } \\
\text { ND } \\
\text { ND } \\
148 \\
894 \\
1150\end{array}$ & $\begin{array}{l}\text { ND } \\
\text { ND } \\
\text { ND } \\
\text { ND } \\
\text { ND } \\
\text { ND } \\
\text { ND } \\
20.8 \\
26 \\
\text { ND }\end{array}$ & $\begin{array}{l}\text { ND } \\
\text { ND } \\
\text { ND } \\
\text { ND } \\
\text { ND } \\
\text { ND } \\
\text { ND } \\
\text { ND } \\
\text { ND } \\
\text { ND }\end{array}$ & $\begin{array}{l}\text { ND } \\
\text { ND } \\
\text { ND } \\
\text { ND } \\
\text { ND } \\
\text { ND } \\
\text { ND } \\
\text { ND } \\
\text { ND } \\
\text { ND }\end{array}$ & $\begin{array}{l}5.7 \\
44.2 \\
71.9 \\
52.1 \\
19.4 \\
10.8 \\
11.8 \\
16.2 \\
21.8 \\
31.3\end{array}$ \\
\hline
\end{tabular}


TABLE II

High Salinity Site (Site 1B) - Unvegetated

\begin{tabular}{|c|c|c|c|c|c|}
\hline $\begin{array}{r}\text { Depth } \\
(\mathrm{cm})\end{array}$ & $\mathrm{pH}$ & $\begin{array}{c}\text { Excess } \mathrm{SO}_{4}{ }^{2-} \\
(\mathrm{mM})\end{array}$ & $\begin{array}{l}\text { Fe } \\
(\mu M)\end{array}$ & $\begin{array}{r}\text { Thiol } \\
(\mu \mathrm{M})\end{array}$ & $\begin{array}{l}S(-2) \\
(\mu \mathrm{M})\end{array}$ \\
\hline $\begin{array}{l}0-2.5 \\
2.5-5 \\
5-7.5 \\
7.5-10\end{array}$ & $\begin{array}{l}6.81 \\
6.43 \\
6.51 \\
7.41\end{array}$ & $\begin{array}{c}15.43 \\
20.34 \\
12.7 \\
5.5\end{array}$ & $\begin{array}{r}17 \\
9 \\
30 \\
19\end{array}$ & $\begin{array}{r}3.2 \\
46 \\
\text { ND } \\
\text { ND }\end{array}$ & $\begin{array}{l}<1 \\
410 \\
792 \\
632\end{array}$ \\
\hline
\end{tabular}

High Salinity Site (Site 1B) - Vegetated

$\begin{array}{lllrll}0-2.5 & 6.59 & 16.02 & 23 & 133 & <1 \\ 2.5-5 & 5.04 & 32.39 & 1,900 & 121 & <1 \\ 5-7.5 & 4.82 & 35.44 & \text { NA } & 891 & <1 \\ 7.5-10 & 6.22 & 26.86 & 67 & 9.4 & <1\end{array}$


Figure 1. Location of the Great Marsh, Delaware study site.

Figure 2. Thiol, total iron and pyrite sulfur measurements for cores taken before ( $a$ ) and after ( ) the monthly flood at the high salinity site during June 1986.

Figure 3. Comparison of $\mathrm{pH}$ and sulfate excess data for low salinity ( $a)$, meduim salinity $(x)$ and high salinity ( ) sites in June 1986. Samples were taken before the monthly flood. 
Figure 1.

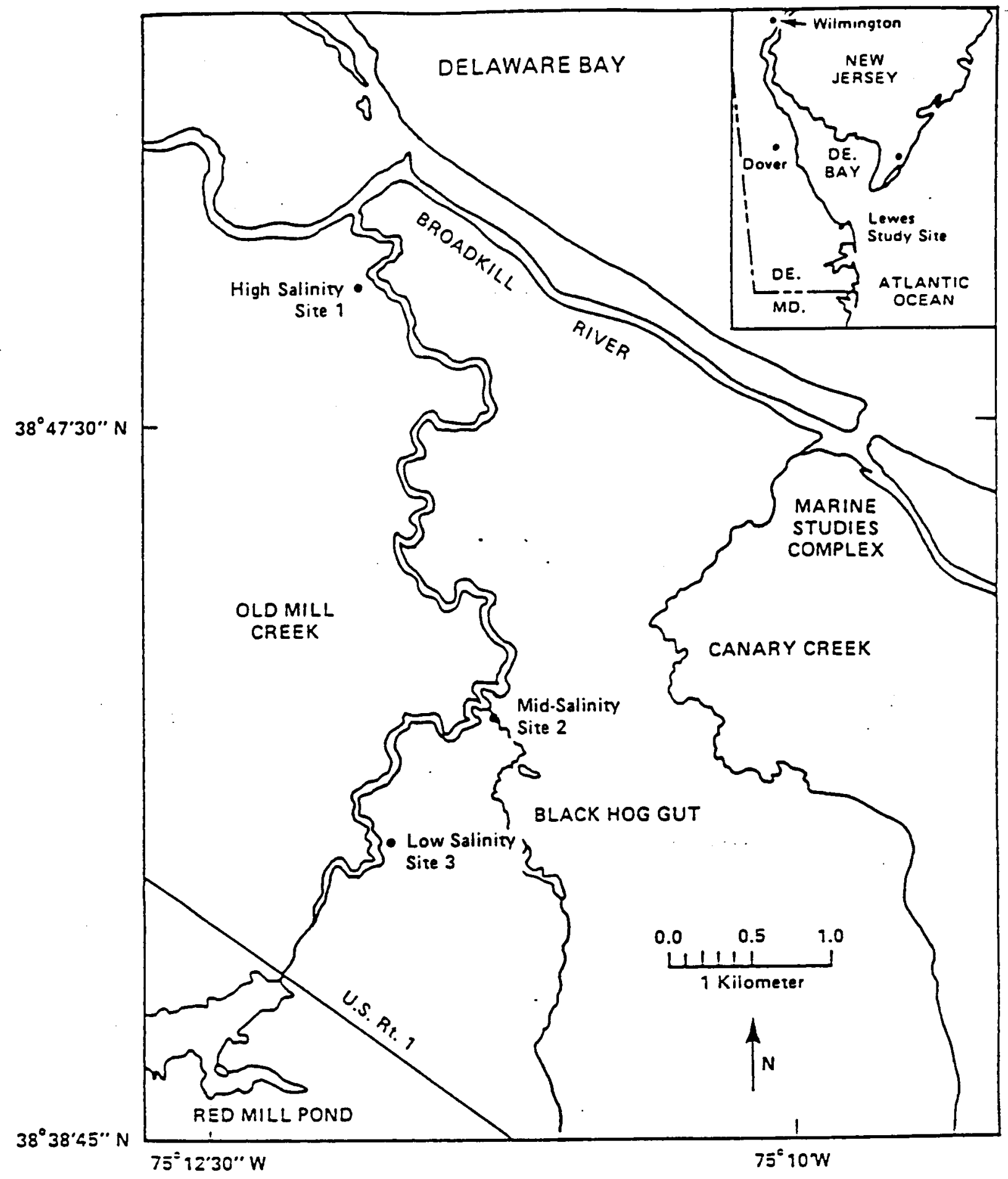


.

Figure 2.
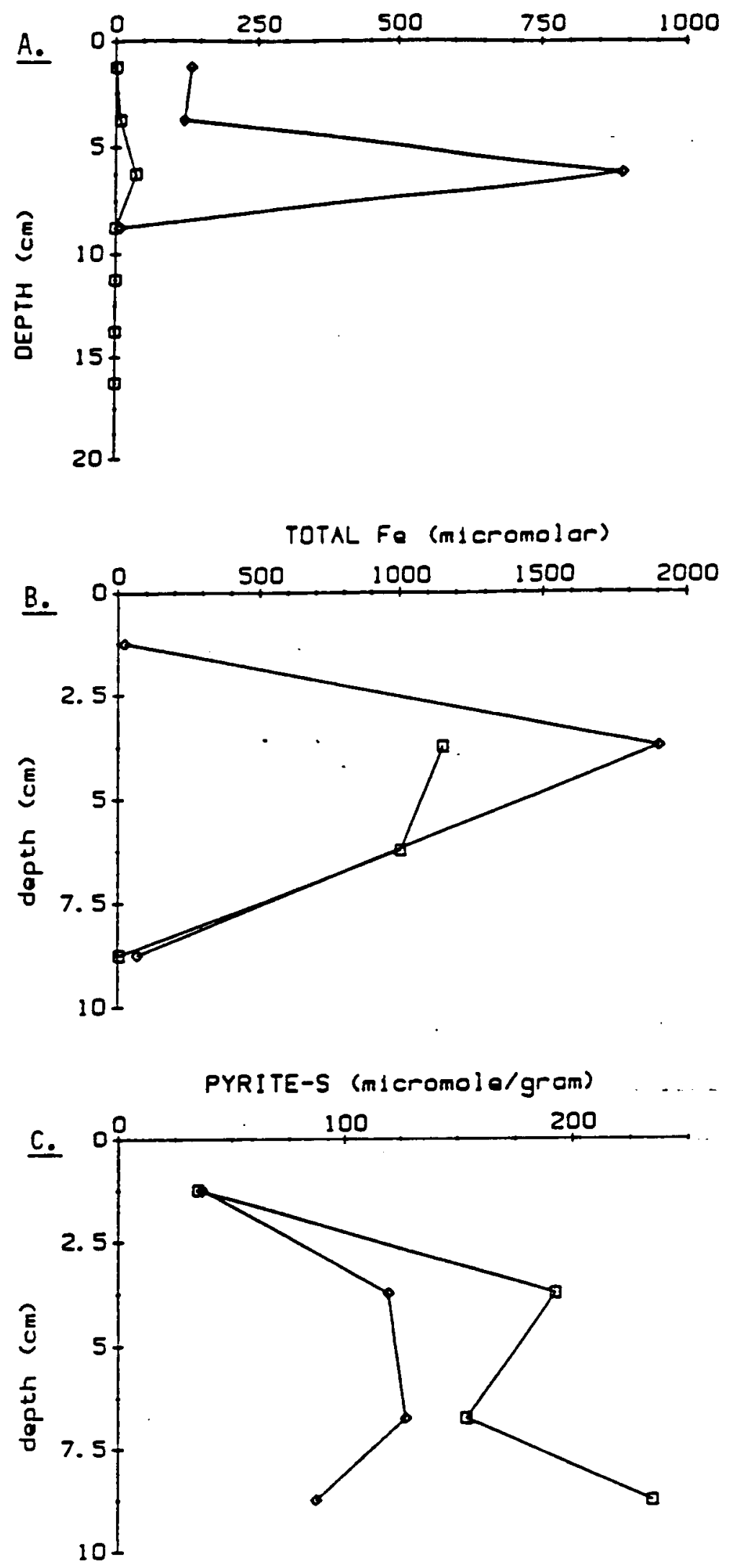
Figure 3.
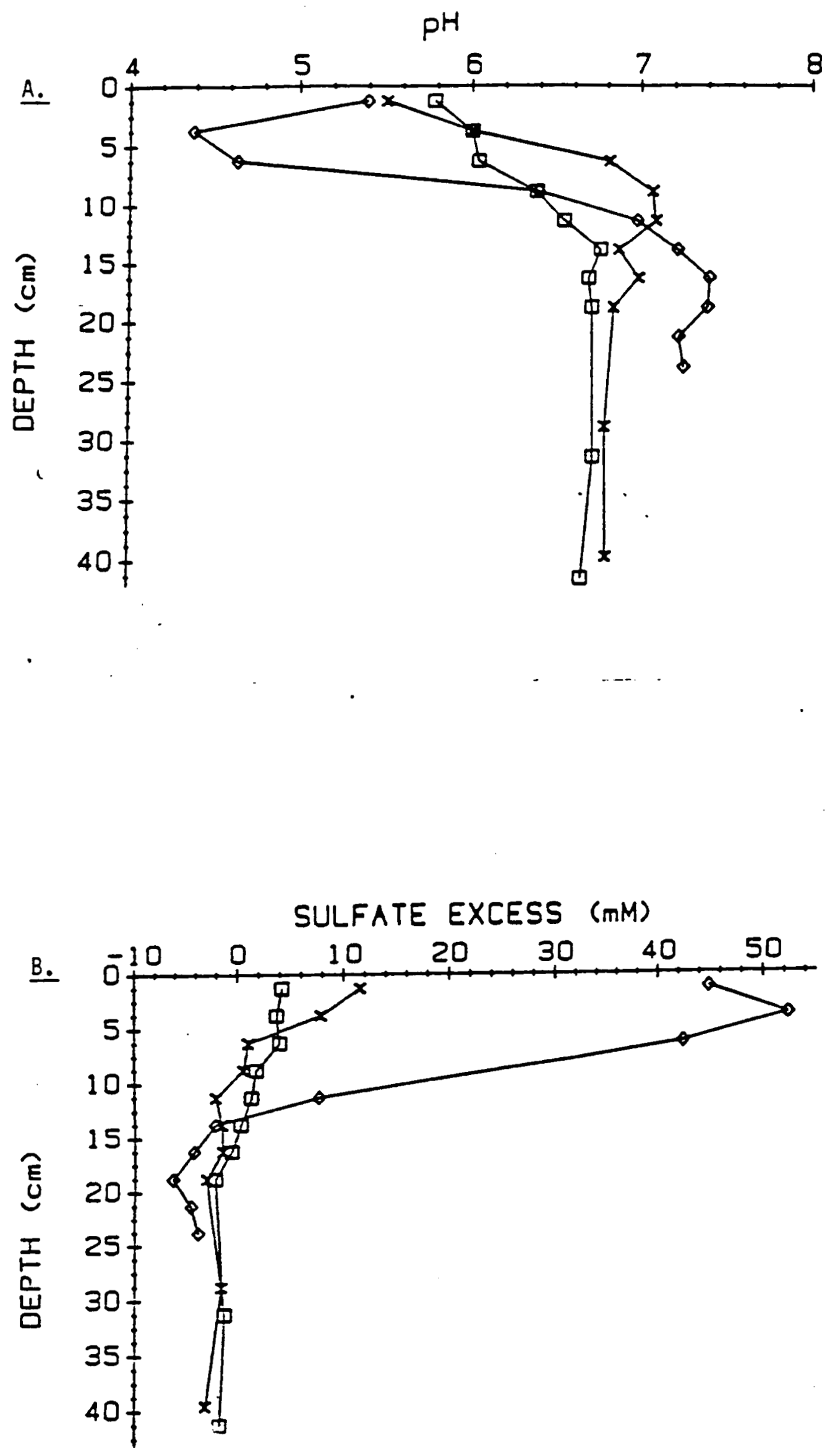